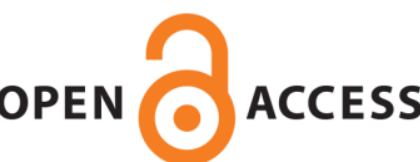

UWS Academic Portal

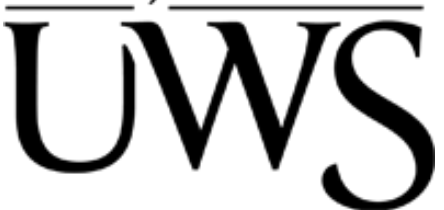

\title{
Planning for ecotourism in the protected area of Manesht and Ghelarang, Ilam
} Province, Iran

Ahmadi, Mehdi; Khodadadi, Masood; Shahabi, Himan

Published in:

Journal of Quality Assurance in Hospitality \& Tourism

DOI:

10.1080/1528008X.2017.1394956

E-pub ahead of print: 08/12/2017

Document Version

Peer reviewed version

Link to publication on the UWS Academic Portal

Citation for published version (APA):

Ahmadi, M., Khodadadi, M., \& Shahabi, H. (2017). Planning for ecotourism in the protected area of Manesht and Ghelarang, Ilam Province, Iran. Journal of Quality Assurance in Hospitality \& Tourism.

https://doi.org/10.1080/1528008X.2017.1394956

\section{General rights}

Copyright and moral rights for the publications made accessible in the UWS Academic Portal are retained by the authors and/or other copyright owners and it is a condition of accessing publications that users recognise and abide by the legal requirements associated with these rights.

Take down policy

If you believe that this document breaches copyright please contact pure@uws.ac.uk providing details, and we will remove access to the work immediately and investigate your claim. 
Title: Planning for Ecotourism in the Protected Area of Manesht and Ghelarang, Ilam Province, Iran

Corresponding author: Mr Mehdi Ahmadi

Corresponding author's e-mail: $\underline{\text { m.ahmadi@ tabrizu.ac.ir }}$

Corresponding author's telephone: 00989189485170

Corresponding author address: Department of Geomorphology, Faculty of Geography and Planning, Tabriz

University, Iran

Second author: Dr Masood Khodadadi

Second author's email: Masood.Khodadadi@uws.ac.uk

Second author's address: School of Business and Enterprise, University of the West of Scotland, Paisley, United Kingdom

Third author: Dr Himan Shahabi

Third author's email: h.shahabi@uok.ac.ir

Third author's address: Department of Geomorphology, Faculty of Natural Resources, University of Kurdistan, Iran 


\title{
Planning for Ecotourism in the Protected Area of Manesht and Ghelarang, Ilam Province, Iran
}

\begin{abstract}
This paper reports a study of the Manesht and Ghelarang protected area in Iran. The study sought to identify ways in which sustainable tourism policies could be generated that aid the natural and human environments. From surveys and questionnaires completed by tourists, residents and officials, an initial set of 10 areas of weakness, 9 strengths and 6 opportunities were identified. Using these classifications combined with mapping techniques that included maps of topography and flora, a subsequent TOPSIS analysis identified potential future policies that require infrastructure development and reinforced pro-environmental policies to address the problems currently being experienced.
\end{abstract}

Key words: Ecotourism; Iran tourism; sustainable tourism; tourism planning; tourism development. 


\section{Introduction}

Rural tourism and - in particular - ecotourism brings money and people from concentrated centers into rural regions. Income resulting from ecotourism contributes to the economy and the social well-being of the host country (Carter, 1994). Many countries around the world have made significant investment in these sectors due to their substantial income generating potentials (Tremblay, 2006). The development and expansion of ecotourism is especially popular in developing countries (King and Stewart, 2002). In social terms, ecotourism income can help local government improve social welfare, transportation and facilities (Cater, 1994; Ross and Wall, 1999). The existence of natural and recreational resources leads to the creation of ecotourism industries which are an important source of income for many developing countries (Wall, 1999). Although ecotourism development may cause the loss of native languages and local culture (Miller, 2001), it can lead to the development of educational and cultural conditions in host countries (Brandon, 2001; Zhang and Chan, 2016). In the past half century, ecotourism has shifted from being mainly a local and intra-border activity into a major phenomenon in the world economy. Ecotourism's goal is to achieve conservation and community development through the provision of economic and social incentives to local communities (Bookbinder, 1998; Chapman, 2003; Ross \& Wall, 1999; Scheyvens, 1999; Wunder, 2000). Ceballos-Lascurain (1993) first used the concept of ecotourism. He defined it as a form of environmentally responsible tourism that involves travel and visits to relatively undisturbed natural areas, with the aim of enjoying, admiring and studying nature (the scenery, wild plant, and animals), as well as any cultural aspect (both past and present) found in these areas, through a process that promotes conservation, has a low impact on the environment and on culture, and favors the active and socioeconomically beneficial involvement of local communities.

Ilam is one of the oldest civilizations of ancient Iran. The province is rich in diversity of flora and fauna, historical and cultural places as well as climatic conditions. Despite its great potentials for tourism, conservation and research values, the use of these capabilities requires careful and comprehensive planning which is still in early stages in the province. The procedure of studying the protected area is considered to be a starting point in protecting vulnerable areas and preventing the destruction of valuable natural resources. Protected areas present the best conditions for biodiversity in natural conditions (Majnunian, 2001), therefore, could maintain their existence if they are recognized and protected by decision-makers and local populations. Zoning these areas and creating efficient management programs (protective, research, instructional and recreational) is the first step in exposing the potential capabilities of 
these area (Najmizade and Yavari, 2006). The protected areas of Manesht and Ghelarang are located in West Iran and are considered special regions in light of their natural and ecological qualities. The idea of ecotourism in the protected area of Manesht and Ghelarang, Ilam Province, Iran is not a pioneering one. However, most of the studies until now have explored the potential from an ecotourism context and have identified user or visitor segments empirically. Therefore, the main objective of this study was to assess and compare the two SWOT and TOPSIS models that have been used for ecotourism in the study area. Although these two models have been used to assess sustainable development in the literature, a comparison of ecotourism among three selected groups-tourists, local people and officials - in the study area has rarely been carried out. Therefore, this study aims to fill this gap in the literature.

\section{Literature Review}

The notion of sustainable development emerged in the 1980s. Sustainable development is a pattern of resource management that aims to meet the needs of human beings not only in the present but also in the indefinite future (Jabareen, 2008). The most often-quoted definition of sustainable development is offered by the Brundtland Commission: "the development that meets the needs of the present without compromising the ability of future generations to meet their own needs" (Brundtland, 1985). As the concept of sustainable development emerged, it was recognized that there was a need to link the conservation of resources with the development needs of rural populations who depend on these resources (Gilmour, 1995). The scientific analysis and evaluation of mentioned capabilities, along with the observation of environmental problems and participation of the people, are necessary for sustainable development (Woodly, 1993; Ashok et al., 2017). Protecting Biodiversity - through sustainable development - has been one of the serious academic challenges of the past three decades (Budowski, 1976; Soulé, 1987; Giannecchini, 1993; Primack, 1998; Clifton and Benson, 2006). Ecotourism can be regarded as a tool for contributing to sustainable development and is considered to be the best approach compatible with the environment (Hunter, 1997). It guarantees the sustainable use of environmental resources, while generating economic opportunities for local people (Farrell and Runyan 1991; Bhattacharya, Chowdhury and Sarkar, 2011).

Ecotourism development integrates the environment with development based on the ecological, economic, social and institutional pillars of sustainability (Warner, 1997). Also, many scholars have noted that changes in economic, social and environmental dimensions are the main factors influencing sustainability, and that these three dimensions influence each other (McCool, 1995; Briassoulis, 2001; Twining-Ward and Butler, 2002). Ecotourism is one aspect 
consistent with nature (Hunter, 1997). It can also create benefits for local residents by attracting international support for the protection of regions, improving the income of poorer classes in society, supporting native sports (Mbaiwa and Stronza, 2010) and enhancing the life of local societies. In addition, it can have positive effects on land values and thus support land use activities such as grazing and agriculture (Mbaiwa and Stronza, 2010). Several recent papers have analyzed sustainable development patterns in the tourism and ecotourism sector (Dye and Shaw, 2007; Lee and Mjelde, 2012; Lai and Nepal, 2006; Shaw et al., 2008; Baral et al., 2007; Turner et al., 1995; Laughland et al., 1996), mainly focusing on the role of ecosystem services in the rapid development of ecotourism. In the field of ecotourism, a number of studies have been carried out in Iran focusing on protected areas (Saeb et al., 2012; Reihanian et al., 2012; Momeni, 2012; Barzekar et al., 2011; Mokhtarshahi et al., 2012; Jozi et al., 2010; Tabibi et al., 2011). There are also some relevant research projects conducted by the Department of Environment of Ilam Province on ecotourism development (Ahmadi et al., 2015). Therefore, the creation of ecotourism requires that the people are supported and engaged (Yoon, 2001) and ecotourism development must increase the maximum participation of local societies in order to protect natural regions (Jiang, 2008).

\subsection{Ecotourism Tourism Potential in Iran}

Iran is a country with substantial tourism potentials. It has an extraordinary tourism position due to its rich cultural, historical and natural assets. For instance, Iran's rich culture and history is a magnet for older, higher-spending age groups. It is also home to very attractive nature and a diverse terrain with 'opportunities for ecotourism, hiking, trekking, cycling and, more interestingly, skiing which is emerging as a key activity attracting residents of the region and beyond' (Euromonitor International, 2016: 2). Due to its territorial diversity, historical/cultural attractions and biological diversity, Iran enjoy a relatively advantageous position in the field of eco-tourism as compared to other branches of tourism (Zangiabadi et al., 2006; Tavangar, 2010). Iran is not yet an ecotourism destination for international visitors and the market is dominated by domestic travelers (Tavassoli, 2002). More importantly, Iran's tourism industry has been suffering from a range of issues over the past three decades, including the over-reliance on oil revenues, negative imagery, international sanctions, political instability and conflicts in the Middle East region, and poor management (Khodadadi, 2016). The recent nuclear agreement - reached in Vienna on 14 July 2015 - and the subsequent softening of relations with the west has opened the doors to a brighter future for the country (Khodadadi, 2016). For instance, the director of Iran's Cultural Heritage, Handicrafts and Tourism Organisation claims 
that 'Iran plans to annually attract 20 million tourists by 2025 which could generate $\$ 30$ billion of revenues' (Press $\mathrm{TV}, 2015)$. If this becomes a reality, tourism will be an important economic activity and source of income for Iran, especially in many of its rural regions.

\section{Study Area}

The protected area of Manesht and Ghelarang covers 30,000 hectares and is located between the protective jurisdictions of Ilam, Ivan and Shirvan Chardavol towns (Fig. 1). The general vegetation includes chestnut trees and the mountainous parts are covered by wheat fields and shrubbery. The altitude of this region ranges from $1400 \mathrm{~m}$ to $2700 \mathrm{~m}$. The precipitation of the study area ranges between $800-1050 \mathrm{~mm}$ and mean annual temperature is $6-14^{\circ} \mathrm{C}$. It became a protected area under the control and management of the Department of Environment of Iran in 1996; however, threats to its unique environmental characteristics are increasingly evident (Ahmadi et al., 2015). Implementation of practical and successful management in this region requires a comprehensive study of the area so that in addition to its ecological values, the potential capabilities of the region can also be identified (Makhdoum, 2008).

Fig. 1. General position of the Manesht and Ghelrang protected area in relation to provincial and national borders.

\subsection{Ecotourism Resources of the Region}

The region has an array of resources which could be utilized to attract potential tourists to the region. These include (but not limited to): Miantang (Hivanan Strait): This strait with its 50 hectares area is located inside the protected area which because of high amount of underground waters is always verdant. This region is one of the most important recreation sites because of its water resource, stunning landscapes, suitable plant cover, easy access and sufficient security. As a result it is always attractive to tourists (Ahmadi, 2007). Dalab Strait: Dalab promenade constitutes a vast area and considering its warm climate attracts tourists particularly in spring and summer (Hatami, 2014). Arghavan Strait: This strait is located $3 \mathrm{~km}$ from Ilam City near the new Azadi Tunnel. It features substantial chestnut forests on both sides of the road; stony and beautiful cliffs of the mountain; promenade and arkavan trees along the strait; rare plant species such as gavan; and a flourishing apiary industry in the mountains producing pure Ilam honey during summer months. Chehel Sotoon Cave (40-column Cave): This cave in located in the east of Manesht and Ghelarang protected area in hillside of Ghelarang Mountain. Because of the water resource inside the cave and 
existence of wildlife, it has attracted significant number of tourists. Abdalan Cave: This Cave is located in the Manesht Mountain and reaching its inside without professional equipment is almost impossible because of the stone and soil types of the region and erosion that has resulted over time. Erosion rocks: Important stones of the region which have ecotourism value are Seshkalan in the west and kilometer 25 of Ilam - Kermanshah road (Figure 2). Inverted Tulip: The Inverted Tulip grows from early April to late June months in Dalab strait and on the hillsides of Manesht Mountain and Shalam Mountain which creates picturesque landscapes.

Figure 2: Summary of ecotourism resources of the region: (a) Dalab Strait; (b) Arghavan Strait; (c) Hivanan Strait; $(d, e)$ manesht protected area; (f) Vegetation and erosion rocks of Seshkalan in the northwest of the protected area.

The above are some of the many ecotourism resources that the region has to offer. If utilized properly, these resources could be key to attracting tourists to the region.

\section{Materials and Methods}

\subsection{Data Collection and Analysis}

In this research, it was aimed to determine ecotourism developments by using SWOT analysis in the protected area of Manesht and Ghelarang. SWOT analysis is a method related to the analysis of the situation of the area in terms of internal (strengths and weaknesses: SW) and external (opportunities and threats: OT) factors. In order to achieve the research goals, SWOT and TOPSIS methods were used. The data collection was carried out between March and July of 2016. Preliminary information and data was collected by both desk research and field studies. In order to evaluate the ecological capability of the protected area (Fig. 3 and Fig. 4) and hazard map (Fig. 4), maps of topography, land cover, slope, land use and hydrology were used. The topographic map of the study area at the scale of 1:50,000 was used to extract some geomorphological features, including faults, ridges, and elevation points. The slope map was extracted from the Digital Elevation Model (DEM) to specify areas with a slope of higher than 20\%, which are suitable for rock climbing, hiking in steep terrain, mountaineering and hillside climbing. The map of fragile habitats was obtained from the Administration of Environmental Protection in Ilam Province.

\subsection{Sampling}


The target individuals included 25 officials, 180 local residents and 260 tourists. The geographical area of the research was the protected area Manesht, Bankol and Qalarang in the Northern of Ilam Province. Questionnaires were designed according to a 5-point Likert spectrum and based the questions in Table 1 to evaluate the strengths, weaknesses, opportunities and threats in the protected area of Manesht and Ghelarang to creating efficient management programs (protective, research, instructional and recreational). Random sampling method was used to identify the sample size, the selected sample was including of local residents, tourists, and official. For populations that are large, the Cochran (1963:75) equation yields a representative sample for proportions. To identify the sample size Cochran equation was used in the following equation:

$n_{o}=\frac{Z^{2} p q}{e^{2}}$

Where: $\mathrm{n}_{0}$ is the sample size,

$\mathrm{Z}^{2}$ is the abscissa of the normal curve that cuts off an area $\alpha$ at the tails; $(1-\alpha)$ equals the desired confidence level, e.g., $95 \%)$

$\mathrm{e}$ is the desired level of precision,

$\mathrm{p}$ is the estimated proportion of an attribute that is present in the population, and $\mathrm{q}$ is $1-\mathrm{p}$.

The value for $\mathrm{Z}$ is found in statistical tables which contain the area under the normal curve. e.g $\mathrm{Z}=1.96$ for $95 \%$ level of confidence.

In this equation, using a confidence level of 95 percent, the error rate of $5 \%$ and variance of $25 \%$ the sample size based Cochran equation was identified.

The following equation was used to simplify the sample size:

$$
n=\frac{N}{1+N(e)^{2}}
$$

Where:

$\mathrm{n}$ is the sample size,

$\mathrm{N}$ is the population size,

e is the level of precision.

The following equation was used to corrected formulae: 


$$
n=\frac{n_{o}}{1+\frac{\left(n_{o}-1\right)}{N}}
$$

Where:

$\mathrm{n}$ is the sample size

$\mathrm{N}$ is the population size.

$\mathrm{n}_{\mathrm{o}}$ is calculated sample size for infinite population

\subsection{SWOT and TOPSIS Analysis}

In the next step, the SWOT matrix was used to analyze the data and to generate tourism development strategies. A list of strengths, weaknesses, opportunities and threats was identified and the priorities were determined by asking tourism officials, local residents and tourist's ideas in the region. In order to overcome or to decrease weaknesses and threats, and to promote and improve strengths and opportunities, relevant to tourism development in the studied region, suitable strategies were provided and the SWOT technique was used to rate the effects of strengths, weaknesses, opportunities and threats from the perspective of the local residents, tourists and officials.

Finally, the TOPSIS model, as an efficient multi-index decision-making method, was used for rating the results in terms of strengths, weaknesses, threats, and opportunities. The Technique for Order of Preference by Similarity to Ideal Solution (TOPSIS) is a multi-criteria decision analysis method, which was originally developed by Hwang and Yoon (Hwang and Yoon, 1995). TOPSIS is based on the concept that the chosen alternative should have the shortest geometric distance from the positive ideal solution (Hwang, 1993) and the longest geometric distance from the negative ideal solution (NIS) (Assari, 2012). Using TOPSIS four weaknesses, opportunities, threats and strengths were classified.

Every problem in the TOPSIS technique includes 7 steps, which are as follows:

1. The matrix is converted to an un-scaled matrix with the help of the Euclidean norm (the resultant is called ND) (Eq. 4):

$$
r_{i j}=\frac{r_{i j}}{i=\left(q^{m} r_{i j}\right)^{\frac{1}{2}}},(j=1, \ldots, n)
$$

2. A balanced un-scaled matrix is achieved by following Eq. (5): 


$$
V=N_{D} W_{N * N}
$$

Where: $\mathrm{V}$ is a balanced un-scaled matrix and $\mathrm{W}$ is a diagonal matrix from achieved weights for the indices.

3. Positive ideal solution (Ai+) determines Negative ideal solution (Ai-). It is achieved by the following Eqs. (6) and (7):

$$
\begin{aligned}
A^{+} & =\left\{\left(\max _{i} V_{i j} \mid J \hat{\mathrm{I}} J_{1}\right),\left(\min _{i j} \mid J \hat{\mathrm{I}} J_{2}\right) \mid i=1,2, \ldots, n\right\} \\
A^{+} & =\left\{\left(\max _{i} V_{i j} \mid J \text { I } J_{1}\right),\left(\min V_{i j} \mid J \text { I } J_{2}\right) \mid i=1,2, \ldots, n\right\} \\
A_{i}^{+} & =\left\{V_{1}^{i^{+}}, V_{2}^{+}, \ldots, V_{n}^{+}\right\} \\
A_{i}^{-} & =\left\{V_{1}^{-}, V_{2}^{-}, \ldots, V_{n}^{-}\right\}
\end{aligned}
$$

4. Distance is achieved, according to Euclidean software, for the negative solution and positive choice and for the positive ideal solution and negative choice by the following Eqs. (8) and (9):

$$
\begin{array}{ccc}
d_{i}^{+}\left\{d_{J=1}^{n}\left(V_{i j}-V_{J}^{+}\right)^{2}\right\}^{\frac{1}{2}} & \text { Where: } & \cdot(i=1,2, \ldots, m) \\
d_{i}^{-}\left\{d_{J=1}^{n}\left(V_{i j}-V_{J}^{-}\right)^{2}\right\}^{\frac{1}{2}} & \text { Where : } & .(i=1,2, \ldots, n)
\end{array}
$$

5. Relative closeness of Ai to the ideal solutions as follows (Eq. 10):

$C_{i}=\frac{d^{-}}{\left(d_{i}^{-}+d_{i}^{-}\right)},(i=1,2, \ldots, n)$

Where: If $\mathrm{Ai}=\mathrm{Ai}+$, then $\mathrm{C}_{\mathrm{i}}=1, \mathrm{di}+=0$ and if $\mathrm{Ai}=\mathrm{Ai}-$, then we have $\mathrm{C}_{\mathrm{i}}=1, \mathrm{di}-=0$. Therefore, the closer the Ai choice is to the ideal solution, the closer the $\mathrm{C}_{\mathrm{i}}$ value would be to 1 .

Rating the alternatives according to $C_{i}$ value, this value varies between $0 \leq C_{i} \leq 1$. In this state, $C_{i}=1$ shows the highest rate and $\mathrm{C}_{\mathrm{i}}=0$ shows the lowest rate.

6. Rating the choices is done in this step and according to the decreasing trend of $\mathrm{C}_{\mathrm{i}}$, we could rate the existing choices according to the greatest significance. In order to analyze the regions' SWOT, relevant information and major internal and external factors were first studied and determined and were put into an evaluation matrix (results of this step are provided in Table 1). Fourteen external factors were identified and recognized, comprised of six factors related to tourist opportunities in the studied regions and eight factors related to the threat of tourism development. There were nineteen internal factors, including nine strengths and ten weaknesses of regional tourism. The next step involved 
prioritizing these factors, considering the preference and significance of each factor by using information gained through questionnaires conducted with the three groups: scholars, local people, and tourists. The results of this step are provided in Tables 2 to 5, each comprised of four main columns. The first, second, third and fourth columns present the four effective factors (strengths, weaknesses, opportunities, and threats), results of polling from officials, results of polling from people in the surrounding regions and the results of polling from tourists in September 2013, respectively. For the main columns of polling from officials, people and tourists, four sub-columns are provided. Generally, the averages of relative weighting and the rating of variables according to their relative weights is presented in columns one, two, three and four, respectively. The weights total is achieved by multiplying the Liker spectrum by their frequency. Also, averages are achieved by dividing total weights by the number of respondents, relative weight by dividing averages by number of respondents and according to the relative weight of each one, as shown in Table 1.

Table 1. SWOT Matrix of Major Factors Influencing on Park Tourism Development

\section{Results and Discussion}

\subsection{Strengths of Ecotourism}

A study of the general status of the Manesht and Ghelarang protected area by extracting information from maps of the region (topography, gradient, land use, plant cover) shows that this region has high natural potential for tourism. More than $56 \%$ of the whole area is covered by chestnut forests with medium crown, $5 \%$ by massive crown chestnut trees, and $14 \%$ by diverse crown. $76 \%$ of the whole area is dominated by forest plants and the rest is mountainous. Also, $8 \%$ of the whole area is covered by high-density stony bulks. The existence of mountains, along with sufficient precipitation and snow storage in winter, with an average temperature of $-7^{\circ} \mathrm{C}$ in the month of January, offers a basis for winter sports. The high density of forest cover, the Ilam to Kermanshah main road, the short distance to the provinces centers (less than $10 \mathrm{~km}$ ), short hillside with high plant and forest density, rare plant species, caves and natural lakes, existence of stony bulks, attractive geomorphologic features such as natural and unique wells (Kabooter well of Manesht), and unique and varied forest plants (Figs. 3 and 4). Therefore, this region has significant potential for ecotourism activity (Ahmadi et al., 2015). 
Figure 3. The Ecotourism Attraction Map in the Protected Area: (a) Suitable zones for individual or family camping; (b) Suitable zone for winter sport; (c) Suitable zone for caving, rock climbing; (d) Suitable zones for family camping.

Figure 4. The Attraction Sites Map of the Protected Area: (a) Geomorphological landforms visit; (b) Hiking in steep terrain; (c) Suitable zones for hillside climbing; (d) Suitable zones for caving, rock climbing and mountaineering.

The results presented in Table 2, indicate the most important internal strengths extracted by SWOT analysis. For officials, the existence of unique geological landscapes with an average rate of 4.07 and relative weight of 0.59 , for local people, the unique diversity of plants with an average of 47 and relative weight of 0.47 , and for tourists, the very suitable climate in the spring with an average rate of 4.78 and relative weight of 0.75 . Meanwhile, according to the responses of all of the groups, the overall strength is based on natural attractions, which shows the region's richness in terms of natural resources and historical features (Table 2).

Table 2. SWOT Analysis Matrix (rating and prioritizing the strengths)

\subsection{Weaknesses of Ecotourism}

The results of Table 3 indicate the most important internal weaknesses. For officials, the lack of planning of leisure centers in the region, with an average rate of 4.32 and relative weight of 0.48 . Local people consider the non-existence of leisure centers as the most important internal weakness with an average of 47 and relative weight of 0.47 . For tourists, the lack of residence is central, with an average rate of 4.4 and relative weight of 0.48 . Lack of leisure and residential centers is considered to be a preventive factor in attracting tourists to the region and this issue is considered to be the major internal weakness by local people and by tourists. The important point in Table 3 is that from the standpoint of officials, lack of planning of leisure centers in the center is the major preventive factor and the most important internal weakness, although the Department of Tourism has the responsibility for implementing such plans. However, in the second and third spectrums, officials consider the lack of facilities to be the major internal weakness. Overall, lack of facilities is the major element of weakness and a reason for why the region is not flourishing (Table $3)$.

Table 3. SWOT Analysis Matrix (rating and prioritizing the weaknesses) 


\subsection{Threats of Ecotourism}

In the study area, the different types of environmental degradation caused by residents include soil and vegetation degradation by off-road and trail use and erosion and forest degradation and habitat disturbance by off-road driving (Fig. 5). This leads to hydrological unbalance, the degradation of forest resources and increased erosion and landslide (Fig. 6). The rating and prorating of important threats to the study area are shown in Table 4. For park officials, these are environmental pollution by desert dust, with an average rating of 4.11 and relative weight of 0.58 , along with drought, for local people, environmental pollution by desert dust with an average of 47 and relative weight of 0.67 , and for tourists, environmental pollution by desert dust with an average of 4.11 and relative weight of 0.58 .

Figure 5. The Map of Environmental and Human Threats in the Study Area

Table 4. SWOT Analysis Matrix (rating and prorating the threats)

Environmental pollution caused by transported desert dust from Iraq and Saudi Arabia during recent years should be considered as a serious crisis. Road construction is one of the hampering factors that could cause widespread destruction (Fig. 6). In the responses of officials, there was an internal factor that was not considered in the spectrum of responses by local people and tourists. This was plant disease, which affects the chestnut forest population. The results of the field survey in the study area by the researcher showed that the destruction of oak trees in some areas is critical (Fig. 6a). This work was carried out in 3 days and the results show that 24 percent of the forests are in danger of destruction (Fig. 6b). This factor relates directly with external factors such as drought and dust from the desert of Iraq and Saudi Arabia. In addition, a small portion of this is due to human activities. In the study area, the IlamKermanshah main road had experienced landslides, the creation of cut slopes through road construction activities, and the loads imposed by construction materials (Fig. 6c and d).

Figure 6. The Degradation of Natural Resources in the Study Area: (a) Destruction of oak trees; (b) Destruction of forest resources by drought; (c) Small debris and landslide along the main road from Ilam to Kermanshah; (d) Landslides caused by the creation of cut slopes through road construction activities. 


\subsection{Opportunities of Ecotourism}

The results of Table 5 indicate the most important opportunities of ecotourism. Employment opportunities for local people, with an average rate of 4.03 and relative weight of 0.59 . Also, for the local people protecting plant and animal life is average of 4.4 and relative weight is 0.62 . Furthermore, for tourists, improving tourism conditions with average rate of 4.51 and relative weight 0.66 be identified as the most important ecotourism opportunities (Table 5).

Table 5. SWOT Analysis Matrix (rating and prioritizing the opportunities)

\subsection{Developing Suitable Strategies for Sustainable Tourism Development of the Region}

\subsubsection{Competitive Strategies}

This set of strategies is created by contrasting strengths and weaknesses. In these strategies, strengths are used in order to impart the prepared opportunities from the external environment. Accordingly, the Competitive Strategies for natural tourism development could be described as follows:

- Planning for tourists for sustainable development of the region in spring and autumn seasons considering the suitable climate of the region in spring and absence of competitive forest region;

- Creating suitable residential infrastructures for travelers entering the region

- Cleaning the region forests from the Loranthus;

- Planning for nature tourism in the region and providing environmental protection training;

- Motivating the local residents to responsibly use the natural attractions of the region;

- Encouraging relevant institutions to integrate ecotourism practices;

- Motivating local residents and neighboring cities in order to reduce waste.

\subsubsection{Diversifying Strategies}


This set was created by contrasting internal strengths with external threats. In these strategies, internal weaknesses are used in order to reduce or to overcome the dangers and threats of external environment. Accordingly, the diversity strategies for natural tourism development in this region could be as follows:

- Hiring tourism professionals;

- Allocating capital and required budget for protective plans such as cleaning the region from harmful pests of chestnut tree and reforestation of degraded areas of the region;

- Allocating sufficient budget for research;

- Creating leisure facilities in focused leisure zones to prevent soil erosion and forest destruction from other zones;

- Taxes on environmental pollution of the region: the individual/company pays tax based on how much they harm the environment;

- Creating specific policies for optimum usage of attractions and preventing their destruction.

\subsubsection{Reconsideration Strategies}

This set was created by contrasting internal weaknesses with external opportunities. According to this set of strategies, usage of external opportunities will increase by reducing the internal weaknesses. Accordingly, reconsideration strategies could be as follows:

- Creating environmentally friendly tourism infrastructures;

- Establishment of well-equipped wild life-watching site in different locations in the park

- Hiring experienced staff to manage the region (the priority of hiring is from surrounding villages);

- Creating residential and recreational centers for the public;

- Increase research funding for scientific studies and research in the area to decrease negative impacts.

\subsubsection{Defensive Strategies}


These strategies were created by contrasting internal weakness and external threats. These strategies attempt to overcome the weaknesses and external threats. It is used through repairing weaknesses to reduce foreign threats. Accordingly, defensive strategies for natural tourism development in this region are as follow:

- Zoning the park according to diversity and tourism activities;

- Create scouting posts in different regions in order to control fire in warm seasons;

- Create closed recreational areas for visitors in cold and rainy seasons;

- Promote development of nature tourism investment in the province and the region;

- Engage stakeholders in the development of tourism facilities/infrastructures

- Use incentives from government in order to attract investment.

Finally, by using TOPSIS model, groups of strengths, weaknesses, threats, and opportunities was rated. The average comments of the three groups-local people, officials and tourists - about strengths, weaknesses, threats and opportunities are weighted using the below formula (Fig. 7).

Figure 7. The Obtained Results from the TOPSIS Model for Four Strategies: weaknesses, threats, strengths and opportunities.

In analyzing the TOPSIS model, weaknesses, threats, strengths and opportunities are ranked first, second, third and fourth, respectively (Table 6). The obtained result indicated that the study area is not developed in comparison to other regions. Weaknesses do not include environmental factors but do include lack of investment and the non-allocation of sufficient funding and attention to this region, which has caused this region to diverge from its development trend. This lack of development starts a destructive process for natural resources, which opens the way for the decay of the ecosystem itself. If there continues to be a lack of strategic planning for its development, this destructive trend could be intensified in the future. Due to lack of development in the study area, poor infrastructure is considered to be a major preventive factor in this research. The natural destruction in the study area is intense and distressing. The development of suitable strategies can decrease the intensity of this crisis and also may open the way for development of this region in future. 
Table 6. Final Alternatives in the TOPSIS Model for the Four Strategies

\section{Conclusion}

One of the necessities of sustainable tourism in protected areas is the protection of natural resources as a collective human legacy. In addition to meeting current generations' needs, sustainable tourism can have the capacity of meeting future generations' needs. Considering the existing attractions of the Manesht and Ghelarang protected area in Ilam, located in West Iran, ecotourism is one of the important topics in the Manesht and Ghelarang protected area. This study examined ecotourism in the protected area of Manesht and Ghelarang of the west Iran. The analysis is based on findings obtained as a result of our survey. As a result of SWOT and TOPSIS analysis, we determined strength and weakness aspects of ecotourism in the protected area of Manesht and Ghelarang which reveal potential opportunities and threats. The findings demonstrate that the area has a wide range of attractive ecotourism resources such as; short hillside with high plant and forest density, rare plant species, caves and natural lakes, existence of stony bulks, attractive geomorphologic features such as natural and unique wells (Kabooter well of Manesht), and unique and varied forest plants. Therefore, this region has significant potentials for ecotourism activity. Considering the privation of these regions that has resulted from a lack of required facilities, ecotourism could offer a source of employment while also creating a motivation for the protection of this rich ecosystem in the long-term and preventing the destruction of sensitive regions. Ecotourism is also believed to contribute to the trend of cultural promotion as an important factor in the sustainable development of the region. In this research, the weaknesses of ecotourism in the study area were determined to be a major and preventive factor in the development of tourism, according to the TOPSIS and SWOT models. Meanwhile, lack of physical infrastructure development is considered to be a major factor, although there are more potential threats than opportunities, and natural and trans-region factors pose more threats than anything else. Therefore, comprehensive protection for the environmental conditions of the study area is necessary: otherwise, the destruction of natural resources in the study area could bring catastrophic results in the future. However, it can be said that, in general, ecotourism based on organized planning, comprehensive research and close attention to the provided strategies could positively affect the region. For the development of tourism and protection of the environment, suitable planning and management is required. In planning for tourist usage of the region, it is necessary that the current levels of demand and supply are identified. Conservation areas of Manesht and Ghelarang with their high ecological value have great tourism potentials. Ecotourism, allowing sustainable 
development in such areas, could not only protect natural and cultural values but also improve socioeconomic level of the region. It is possible to overcome majority of the threats and weaknesses in the area by training expert and educated team of employees in travel agencies, accommodation facilities and by recognizing and introducing ecotourism attractions. However, to develop successful and sustainable tourism in these areas, more research is needed. Particularly, in areas such as geological, geomorphological and hazard mapping, analysis of ecological vulnerability, and detailed documentation and assessment of the significant features that define the region's natural heritage. For a long-term economic benefit of tourism, a sustainable tourism management plan of the region is crucial to ensure that natural resources are conserved, protected and utilized in a sustainable manner. Finally, in order to protect the tourism environment, the demand level should be managed so that the interests of both the native population and tourists can are protected.

\section{Reference}

Ahmadi, M., Faraji Darabkhani, M., \& Ghanavati, E. (2015). A GIS-based multi-criteria decision-making approach to identify site attraction for ecotourism development in Ilam Province, Iran. Tourism Planning \& Development, 12(2), 176-189.

Assari, A., Mahesh, T., \& Assari, E. (2012b). Role of public participation in sustainability of historical city: usage of TOPSIS method. Indian Journal of Science and Technology, 5(3), 2289-2294.

Ashok, S., Tewari, H. R., Behera, M. D., \& Majumdar, A. (2017). Development of ecotourism sustainability assessment framework employing Delphi, C\&I and participatory methods: A case study of KBR, West Sikkim, India. Tourism Management Perspectives, 21, 24-41.

Baral, N., Stern, M. J., \& Heinen, J. T. (2007). Integrated conservation and development project life cycles in the Annapurna Conservation Area, Nepal: is development overpowering conservation? Biodiversity and Conservation, 16, 2903-2917.

Barzekar, G., Aziz, A., Mariapan, M. (2011). Delphi technique for generating criteria and indicators in monitoring ecotourism sustainability in Northern forests of Iran: case study on Dohezar and Sehezar Watersheds. Forestalia Polonica Series A, 53(2): 130-141. 
Bhattacharya, D., Chowdhury, B.and Sarkar,R. (2011). Irresponsıble Ecotourısm Practıces Flankıng the Best Natıonal Park in Indıa: A Multıvarıate Analysıs. 2nd Internatıonal Conference on Busıness and Economıc Research (2nd Icber 2011) Proceeding, 1901-1928.

Bookbinder, M. P., Dinerstein, E., Rijal, A., Cauley, H., \& Rajouria, A. (1998). Ecotourism's support of biodiversity conservation. Conservation Biology, 12(6), 1399-1404.

Brandon, K. (2001). Moving beyond integrated conservation and development projects (ICDPs) to achieve biodiversity conservation. In D. R. Lee, \& C. B. Barrett (Eds.), Tradeoffs or synergies? Agricultural intensification, economic development and the environment (pp. 417-432). New York, NY: CABI Publishing.

Briassoulis, H. (2001). Sustainable development and its indicators: through a glass darkly. Journal of Environmental Planning and Management, 44(3), 409-427.

Brundtland, G. H. (1985). World commission on environment and development. Environmental Policy and Law, 14(1), 26-30.

Budowski, G. (1976). Tourism and environmental conservation: conflict, coexistence or symbiosis? Environmental Conservation, 3, 27-31.

Carter, E. (1994). Ecotourism in the third world: problems and prospects for sustainability. In E. Cater, \& G. Lowman (Eds.), Ecotourism: A sustainable option? (pp. 69-86). Chichester: Wiley.

Ceballos-Lascurain, H. (1993). Ecotourism as a worldwide phenomenon. In K. Lindberg, \& D. Hawkins (Eds.), Ecotourism: A guide for planners and managers. Mexico journal. p. 12-14.

Chapman, D. (2003). Management of national parks in developing countries - a proposal for an international park service. Ecological Economics, 46, 1-7.

Clifton, J., \& Benson, A. (2006). Planning for sustainable ecotourism: the case for research ecotourism in developing country destinations. Journal of Sustainable Tourism, 14(3), 238-254.

Dye, A. S., \& Shaw, S.-L. (2007). A GIS-based spatial decision support system for tourists of the Great Smoky Mountains National Park. Journal of Retailing and Consumer Services, 14(4), 269-278.

Euromonitor International. (2016). Travel in Iran. Retrieved from https://www.portal.euromonitor.com November 8.

Farrell, B.H., \& Runyan D. (1991). Ecology and Tourism. Annals of Tourism Research, 18, 26-40.

Giannecchini, J. (1993). Ecotourism: new partners, new relationships. Conservation Biology, 7, 429-432. 
Gilmour, D. A. (1995). Collaborative management of forests for conservation and development issues in forests conservation. Issues in Forests Conservation. IUCN, Gland.

Hatami Nasari, T. Asgari.S. Ahmadi, M. (2014) The study of environmental ecological power based on systematic analysis models (case study Ilam province), science road journal, Volume: 01, Pp: 24-32.

Hunter, C. (1997). Sustainable tourism as an adaptive paradigm. Annals of Tourism Research, 24, 850-867.

Hwang, C.L.; Lai, Y.J.; Liu, T.Y. (1993). A new approach for multiple objective decision making. Computers and Operational Research. 20, 889-899.

Jabareen, Y. (2008). A new conceptual framework for sustainable development. Environment, Development and Sustainability, 10(2), 179-192.

Lai, P. H., \& Nepal, S. K. (2006). Local perspectives of ecotourism development in Tawushan Nature Reserve, Taiwan. Tourism Management, 27(6), 1117-1129.

Jiang, J. (2008). Evaluation of the Potential of Ecotourism to Contribute to Local Sustainable Development: A Case Study of Tengtou Village, China; Ph.D. Thesis; Massey University: Massey, New Zealand.

Jozi, S. A., Aghapour P., Khalilzadeh Poshtegal. M. (2010). Presentation of strategic management plan in ecotourism development through SWOT: case study of Qeshm Island. Journal of Food, Agriculture and Environment, $8(2), 1123-1132$.

Khodadadi, M. (2016). Challenges and opportunities for tourism development in Iran: Perspectives of Iranian tourism suppliers. Tourism Management Perspectives, 19, 90-92.

King, D., \& Stewart, W. (1992). Ecotourism and commodification: protecting People and Places. Biodiversity and Conservation, 5, 293-305.

Laughland, A. S., Musser, W. N., Shortle, J. S., \& Musser, L. M. (1996). Construct validity of averting cost measures of environmental benefits. Land Economics, 72 (1), 100-112.

Lee, C. K., Mjelde, G. W. (2012). Valuation of ecotourism resources using a contingent valuation method: the case of the Korean DMZ. Ecological economics, 63, 511-520.

Makhdoum, M. F. (2008). Management of protected areas and conservation of biodiversity in Iran. International Journal of Environmental Studies, 65(4), 563-585.

Majnunian, H. (2001). Environmental capability assessment of Londavil Wildlife Refuge. Journal of Environmental Studies, 27, 23-33. 
Mbaiwa, J. E, \& Stronza, A. L. (2010) The effects of tourism development on rural livelihoods in the Okavango Delta, Botswana. Journal of Sustainable Tourism, 18(5), 635-656.

McCool, S. F. (1995). Linking tourism, the environmental, and concepts of sustainability: setting the stage. In S. F. McCool, \& A. E. Watson (Eds.), Comps. Linking tourism, the environmental, and sustainability. Gen. Tech. Rep. INNNT -GTR-323. Ogden, UT: USDA, Forest Service, Intermountain Research Station.

Mehrpress (2012) welcomes 20 million tourists to Iran in 2024 from promises to reality Retrieved 23.01 .2012 athttp://www.Mehrpress. Com/About/14254.

Miller, G. (2001). The development of indicators for sustainable tourism: results of a Delphi survey of tourism researchers. Tourism Management, 22(4), 351-362.

Mokhtarshahi Sani R., \& Mahasti P. (2012). Regenerating regional identity for sustainable tourism development case study, Eslami Island, Iran. Procedia - Social and Behavioral Sciences, 35, 523-530.

Momeni M. (2012). Iran's role in the development of ecotourism and sustainable development of protected areas. American Journal of Scientific Research, 50, 112-118.

Najmizadeh, S., \& Yavari, A. R. (2006). Zoning and planning of Khabr National Park with the aid of GIS. Journal of Environmental Studies, 38, 47-58.

Primack, R. B. (1998). Essentials of conservation biology (2nd ed.). Sunderland, Mass.: Sinauer.

Press TV (2015). Iran tourism catches eye of big hoteliers. Retrieved from http://www.presstv.ir/Detail/2015/05/30/413490/iran-tourism-hotels-investment (May 30)

Reihanian A., Noor Z. M., Kahrom E. (2012). Sustainable tourism development strategy by SWOT analysis: Boujagh National Park, Iran. Tourism Management Perspectives, 4, 223-228.

Ross, S., \& Wall, G. (1999). Ecotourism—-toward congruence between theory and practice. Tourism Management, $20,123-132$.

Saeb K., Jafari Hajati, R., \& Rezai, S. (2012). An investigation into eco-tourism potential of the Alamut region of Iran using SWOT analysis model. Ecologia Balkanica, 4(1), 9-20.

Scheyvens, R. (1999). Ecotourism and the empowerment of local communities. Tourism Management, 20, $245-249$.

Shaw, S. L., Yu, H., \& Bombom, L. S. (2008). A space-time GIS approach to exploring large individual-based spatiotemporal datasets. Transactions in GIS, 12(4), 425-441. 
Soulé, M.E., (1987). News of the society. Conservation Biology, 1: 4-5.

Tabibi, M., \& Rohani, A. (2011). Jet Ski development strategies: the case of Caspian Sea's south-west beach. Tourismos: An International Multidisciplinary Journal of Tourism, 6(2), 175-192.

Tavangar M. (2010). Importance of Sistan and Baluchestan Ecotourism. Affiliation, Urban planning Department Iranian Academic Center for Education Culture and Research. Mashhad, Iran.

Tavassoli K. (2002). Ecotourism in Iran: In: Linking Green Productivity to Ecotourism (Chapter 12: Ecotourism in Iran) (Tundloe T, ed). Asian Productivity Organization, Tokyo, Japan.

Tremblay, P. (2006). Desert tourism scoping study, Desert knowledge CRC (Report 12, 0: 52). Darwin: Charles Darwin University.

Turner, R. K., Folke, C., Gren, I. M., \& Bateman, I. J. (1995). Wetland valuation: three case studies. In: C. Perrings, K.-G. Maler, C. Folke, C. S. Holling, B. O. Jansson (Eds.), Biodiversity loss: economic and ecological issues. Cambridge, MA: Cambridge University Press.p:49-129.

Twining-Ward, L., \& Butler, R. (2002). Implementing STD on Small Island: development and use of sustainable tourism development indicators in Samon. Journal of Sustainable Tourism, 10(5), 363-387.

Warner K. (1997). The vision and role of community forestry in sustainable development. Proceedings of the XI World Forestry Congress, held at Antalya (Turkey), Vol. 5, page 57-68.

Woodley, A. (1993). Tourism and sustainable development: The com- munity perspective. In J. G. Nelson, R. Butler, \& G. Wall, Tourism and sustainable development: monitoring, planning, and managing (pp.135 146). Waterloo: Heritage Resources Centre, University of Waterloo.

Wunder, S. (2000). Ecotourism and economic incentives: an empirical approach. Ecological Economics, 32(3), 465479.

Yoon, K. P., \& Hwang, C. L. (1995). Multiple attribute decision making. An introduction. California. SAGE Publications.

Yoon, Y., Gursoy, D., \& Chen, J. S. (2001). Validating a tourism development theory with structural equation modeling. Tourism Management, 22(4), 363-372.

Zangiabadi A, Mohamadi J, Zirakbash D. (2006). The analysis of domestic tourism of Isfahan city. Journal of Geography and Development (In Persian), 4(8): 463-470. 
Zhang, S., \& Chan, C. S. (2016). Nature-based tourism development in Hong Kong: importance-performance perceptions of local residents and tourists. Tourism Management Perspectives, 20, 38-46. 